\title{
JPCS
}

Peqguruang: Conference Series

elSSN: 2686-3472

Vol. 3 No. 2 Nov. 2021

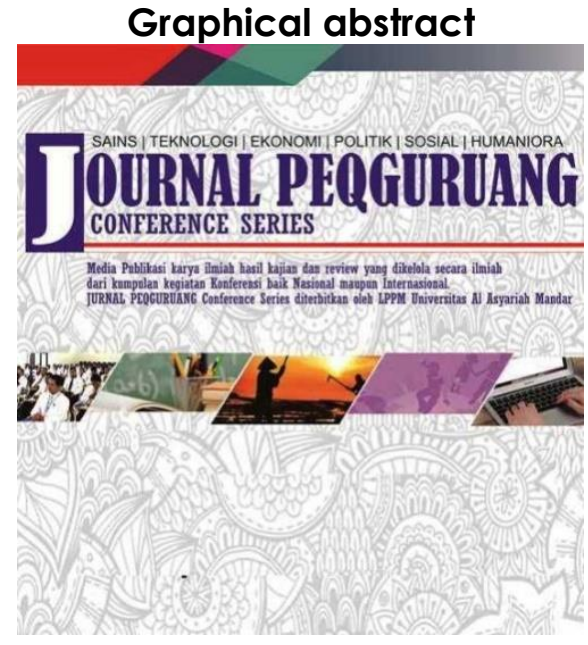

\section{METODE PEMBELAJARAN \\ SOLVING TERHADAP HASIL \\ PROBLEM \\ MATEMATIKA SISWA KELAS VIII SMP KRISTEN KONDOSAPATA}

1*Alvi Krismayanti, ${ }^{2}$ Kamaruddin Tone, ${ }^{3}$ Fatimah

Program Studi Pendidikan Matematika Fakultas Keguruan dan Ilmu Pendidikan, Universitas Al Asyariah Mandar

Corresponding author

*alvikrismayantihadry@gmail.com

\begin{abstract}
The studi was carried out at the 2019/2020 Christian school of condosapata with a view to learning the affects of the methods of constructive problem study of mathematics. This is a study of experimentation. The data -gathering teachnigue is done by providing tests and observations of learners activities. Recearch results in analysis with a descriptive andinferential analysis. The result of theadvanced analisis of the pretest avarage volue experiment 49,17 after treatment of the method of problem, avarage posttest education avarage increased to 81,66 . the pretest volue control class was 49,65 after postest the avarage value posttest ofliteracy rose to 60,59 . Based on inferential analisys of independent tests the tests for data posttest by both goups of value ( 2 -tailed) $0,000<0,05$ and values $t_{\text {hitung }} 3,886$ so $t_{\text {hitung }} 4,594>$ $t_{\text {tabel }}$ 1.660. Then this shows that $H_{0}$ rejec and $H_{1}$ accepted. So it can be argued that the method of study ofthe various problems affected the results of studying the eighth ofthe Christian high school math class.
\end{abstract}

Keywords: Problem Solving:results from learning,mathematics

\begin{abstract}
Abstrak
Penelitian ini dilaksanakan di SMP Kristen Kondosapata tahun pelajaran 2019/2020 dengan tujuan mengetahui pengaruh metode pembelajaran problem solving terhadap hasil belajar matematika. Penelitian ini merupakan penelitian eksperimen. Teknik pengumpulan data dilakukan dengan cara memberikan tes, dan pengamatan aktivitas peserta didik. Penelitian dianalisis dengan analisis deskriptif dan inferensial. Hasil analisis deskriptif kelas eksperimen nilai rata-rata pretest yaitu 49,17 diberi perlakuan metode problem solving rata-rata posttest peserta didik menjadi 81,66 . Sedangkan pada kelas kontrol nilai rata-rata pretest yaitu 49,65 , setelah dilakukan posttest nilai rata-rata posttest peserta didik menjadi 60,59. Dilihat dari aktivitas peserta didik rata-rata kelas kontrol persentase $78,59 \%$ dan rata-rata kelas eksperimen persentase $85,75 \%$. Dari analisis inferensial Uji Independent Sample T Test untuk data hasil posttest kedua kelompok data diperoleh sig. (2-tailed) $0,000<0,05$ dan nilai $t_{\text {hitung }} 4.594$ sehingga $t_{\text {hitung }} 4.594>t_{\text {tabel }} 1,660$ Maka ini menunjukkan bahwa $\mathrm{H}_{0}$ ditolahk dan $\mathrm{H}_{1}$ diterima. Jadi dapat disimpulkan bahwa metode pembelajaran problem solving ada perangaruh hasil belajar matematika siswa kelas VIII SMP Kristen Kondosapata.
\end{abstract}

Kata kunci : Problem Solving, Hasil Belajar, Matematika

\author{
Article history \\ DOI: https://dx.doi.org/10.35329/ip.v3i2.1503 \\ Received : 12 Juli 2021 | Received in revised form : 20 Agustus 2021 | Accepted : 22 Oktober 2021
}




\section{PENDAHULUAN}

Pendidikan merupakan salah satu sarana untuk meningkatkan kepribadian, peradaban dan kemajuan bangsa demi bangsa yang akan datang. Pendidikan nasional bersumber pada kebudayaan bangsa Indonesia berdasarkan Pancasila dan UndangUndang Dasar 1945 yang mengamatkan upaya untuk mencerdaskan kehidupan bangsa. Pendidikan nasional berfungsi mengembangkan kemampuan serta meningkatkan mutu kehidupan dan martabat manusia Indonesia dalam rangka mencerdaskan kehidupan bangsa.

Matematika itu bukanlah pengetahuan menyendiri, yang dapat sempurnah karena dirinya sendiri. Tetapi adanya matematika itu terutama untuk membantu manusia dalam memahami dan menguasai permasalahan sosial, ekonomi dan alam.(Ika, 2017)

Pemahaman peserta didik tentang matematika sangatlah dipengaruhi dengan bagaimana guru mendesain sebuah pelajaran matematika, agar mudah dipahami peserta didik. Mengingat bahwa matematika merupakan ilmu yang tergolong sulit untuk dipahami oleh peserta didik pada umumnya, maka model atau metode yang digunakan harus mendukung dan mmudahkan peserta didik dalam memahami pelajaran matematika. (Febryanti, 2017: 65)

Metode pembelajaran adalah cara-cara atau teknik penyajian bahan pelajaran yang akan digunakan oleh guru pada saat menyajikan bahan pelajaran, baik secara individu atau secara kelompok untuk memcapai tujuan pembelajaran.

Problem solving adalah penggunaan metode dalam kegiatan pembelajaran dengan jalan melatih peserta didik dalam menghadapi berbagai masalah baik itu perorangan maupun masalah kelompok untuk dipecahkan sendiri dan atau bersama. Pembelajaran adalah berorientasi investigasi dan penemuan yang pada dasarnya adalah pemecahan masalah.(Nadhiroh, 2017).

Hasil belajar dapat dijelaskan dengan memahami dua kata yang membentuknya, yaitu "hasil", dan "belajar". Pengertian hasil menunjuk pada suau perolehan akibat dilakukannya suatu aktivitas atau proses yang mengakibatkan berubahnya input secara fungsional. Kata hasil merupakan perolehan yang didapatkan karena adanya kegiatan mengubah bahan (raw materials) menjadi barang jadi (finished goods). (Anita, 2016)

Teorema pythagoras adalah hubungan mendasar dalam geometri euclidean diantara tiga sisi segitiga sikusiku ini menyatakan bahwa luas kontak yang sisinya adalah sisi miring adalah jumlah area kotak di dua sisi lainnya. Teorema ini dapat ditulis sebagai persamaan yang menghubungkan panjang sisi a, b dan c, sering disebut persamaan pythagoras.

Penelitian ini bertujuan untuk mengetahui apakah terdapat pengaruh metode problem solving terhadap hasil belaar matematika.

\section{METODE PENELITIAN}

Jenis penelitian ini adalah eksperimen yang melibatkan dua kelas. Desain penelitian yang digunakan adalah Control Group Desaign. Berikut gambar desain penelitian sebagai berikut:

\begin{tabular}{|l|c|c|c|}
\hline Kelas & Pretest & Perlakuan & Posttest \\
\hline Eksperimen & E1 & XE & E2 \\
\hline Kontrol & K1 & XK & K2 \\
\hline
\end{tabular}

Gambar . Desain Penelitian Control GroupDesign

Keterangan:

E1 : pretest kelompok eksperimen

$\mathrm{XE}$ : pemberian perlakuan pada kelompok eksprimen

E2 : postest pada kelompok eksperimen

K1 : pretest kelompok kontrol

XK : pemberian perlakuan pada kelompok kontrol

K2 : posttest pada kelompok kontrol

Intrumen alat bantu yang digunakan oleh peneliti untuk mengumpulkan data penelitian.

1. Tes pemecahan masalah merupakan proses menerapkan pengetahuan yang telah diperoleh sebelumnya pada situasi baru dan berbeda. soal diberikan skor sesuai indikator pemecahan masalah, seperti : 1) memahami masalah, 2) merencanakan penyelesaian, 3) melaksanakan rencana, 4) melihat kembali. (Fatimah, $2017: 12$ )

2. Lember observasi aktivitas yang dilakukan peserta didik saat proses pembelajaran berlangsung.

Teknik analisis ada dua yaitu teknik analis deskriptif yakni dengan menentukan rata-rata kedua kelompok sampel dan analisis inferensial digunakan untuk menguji hipotesis yakni dengan analisis independent sample t-test, namun sebelumnya dilakukan uji normal dan uji homogen.

Indikator pengaruh dalam penelitian ini adalah

1. $\mathrm{H}_{0}$ ditolahk dan $\mathrm{H} 1$ diterima

2. Ketuntasan hasil belajar $100 \%$ dengan KKM ketuntasan adalah 60

\section{HASIL DAN PEMBAHASAN}

Penelitian ini dilakukan sebanyak 3 kali pertemuan per kelas maka menghasilkan data tersebut diolahh data dianalisis guna memperoleh kesimpulan penelitian.

1. Analisis Statistik Deskriptif

Berdasarkan hasil analisis deksriptif nilai tes peserta didik kelas VIIIA dan VIIIB diuraikan berikut: 
Tabel 1. Hasil Analisis Deskriptif Kelas Eksperimen Dan Kelas Kontrol

\begin{tabular}{|l|c|c|}
\hline \multicolumn{3}{|c|}{ Pre test } \\
\hline Kelas & Eksperimen & Kontrol \\
\hline Mean & 49,17 & 49,65 \\
\hline Median & 55,26 & 50,50 \\
\hline Mode & 55,26 & 55,15 \\
\hline St. Deviation & 11,47 & 8,69 \\
\hline Range & 41,02 & 25,52 \\
\hline Minimum & 22,11 & 35,00 \\
\hline Maksimum & 63,13 & 60,52 \\
\hline Sum & 934,29 & 943,50 \\
\hline \multicolumn{2}{|c|}{ Posttest } \\
\hline Kelas & Eksperimen & Kontrol \\
\hline Mean & 81,66 & 67,41 \\
\hline Median & 80,50 & 70,15 \\
\hline St. Deviation & 89,25 & 70,15 \\
\hline Range & 8,03 & 10,87 \\
\hline Minimum & 26,00 & 39,65 \\
\hline Maksimum & 65,25 & 50,35 \\
\hline Sum & 91,25 & 90,00 \\
\hline M & $1.551,70$ & $1.280,84$ \\
\hline
\end{tabular}

Sumber : hasil olahh data SPSS

Berdasarkan tabel 1 menunjukkan pada kelas eksperimen pretest skor rata-rata 49,17 standar deviasi 11,47. Skor terendah yang diperoleh adalah 22,11 dan skor tertinggi adalah 63,13 dari skor ideal 100 yang mungkin dicapai. Selanjutnya pada kelas kontrol pretest skor rata-rata 49,65 standar deviasi 8,69. Skor terendah yang diperoleh adalah 35,00 dan skor tertinggi adalah 60,52 dari skor ideal 100 yang mungkin dicapai.

Kemudian pada kelas eksperimen posttest skor rata-rata 81,66, standar deviasi 8,03. Skor terendah yang diperoleh adalah 65,25 dan skor tertinggi adalah 91,25 dari skor ideal 100 yang mungkin dicapai.

Selanjutnya untuk kelas kontrol posttest skor rata-rata 67,41 , standar deviasi 10,87 . Skor terendah yang diperoleh adalah 50,35 dan skor tertinggi adalah 90 dari skor ideal 100 yang mungkin dicapai. Maka diperoleh distribusi frekuensi dan persentase ketuntasan seperti sebagai berikut:

Tabel 2. Distribusi Dan Persentase Ketuntasan Pretest Kelas Eksperimen Dan Kelas Kontrol

\begin{tabular}{|c|c|c|c|}
\hline \multirow{2}{*}{ Skor } & \multirow{2}{*}{ Kriteria } & \multicolumn{2}{|c|}{ Frekuensi/persentase $\%$} \\
\hline & & Eksperimen & Kontrol \\
\hline \multirow{2}{*}{$0,0<60$} & \multirow{2}{*}{$\begin{array}{l}\text { Tidak } \\
\text { Tuntas }\end{array}$} & 15 & 16 \\
\hline & & $78,94 \%$ & $84,21 \%$ \\
\hline \multirow{2}{*}{$60 \leq 100$} & \multirow{2}{*}{ Tuntas } & 4 & 3 \\
\hline & & $21,05 \%$ & $15,78 \%$ \\
\hline & \multirow{2}{*}{ Jumlah } & \multicolumn{2}{|c|}{19} \\
\hline & & \multicolumn{2}{|c|}{$100 \%$} \\
\hline
\end{tabular}

Tabel 2 menunjukkan pada kelas eksperimen dalam kategori tidak tuntas dari jumlah peserta didik 19 orang diperoleh hasil persentase sebesar 78,94\% lebih tinggi dari skor yang berada dalam kategori tuntas dari jumlah peserta didik 4 orang diperoleh hasil persentase sebesar $21,05 \%$.

Selanjutnya pada kelas kontrol dalam kategori tidak tuntas dari jumlah peserta didik 19 orang diperoleh hasil persentase sebesar $84,21 \%$ lebih tinggi dari skor yang berada dalam kategori tuntas dari jumlah peserta didik 3 orang diperoleh hasil persentase sebesar $15,78 \%$.

Tabel 3. Distribusi Dan Persentase Nilai Posttest Kelas Eksperimen Dan Kelas Kontrol

\begin{tabular}{|c|c|c|c|}
\hline \multirow[b]{2}{*}{ kor $^{\mathrm{S}}$} & \multirow{2}{*}{ riteria } & \multicolumn{2}{|c|}{ Frekuensi/persentase\% } \\
\hline & & $\begin{array}{l}\text { Ekspe } \\
\text { rimen }\end{array}$ & Kontrol \\
\hline \multirow{2}{*}{$0,0<60$} & \multirow{2}{*}{$\begin{array}{l}\text { Tidak } \\
\text { Tuntas }\end{array}$} & 0 & 4 \\
\hline & & $0 \%$ & $21,05 \%$ \\
\hline \multirow{2}{*}{$60 \leq 100$} & \multirow{2}{*}{ Tuntas } & 19 & 15 \\
\hline & & $100 \%$ & $78,94 \%$ \\
\hline & \multirow{2}{*}{ Jumlah } & \multicolumn{2}{|c|}{19} \\
\hline & & \multicolumn{2}{|c|}{$100 \%$} \\
\hline
\end{tabular}

Sumber: hasil olah data SPSS

Tabel 3 menunjukkn pada kelas eksperimen yang berada dalam kategori tidak tuntas sebanyak 0 orang diperoleh hasil persentase sebesar $0 \%$ lebih rendah dari skor yang berada dalam kriteria tuntas sebanyak 19 diperoleh hasil persentase sebesar 100\%.

Selanjutnya pada kelas kontrol yang berada dalam kategori tidak tuntas sebanyak 4 diperoleh hasil persentase sebesar $21,05 \%$ lebih rendah dari skor yang berada dalam kriteria tuntas sebanyak 15 diperoleh hasil persentase sebesar 78,94\%. Maka dapat disimpulkan pada kelas VIII yang menjadi kelas eksperimen mencapai nilai ketuntasan 100\%.

2. Hasil Analisis Inferensial

a. Uji Normalitas

Tabel 4 Tests of Normality Pree-Test Kelas Eksperimen dan Kelas Kontrol

\begin{tabular}{|l|l|c|c|c|c|c|}
\hline \multicolumn{9}{|c|}{ Kolmogorov-Sminov } \\
\hline \multicolumn{9}{|c|}{ Preetest } & \multicolumn{3}{c|}{ Posttest } \\
\hline A & 0,281 & 19 & 0,200 & 0,211 & 19 & 0,026 \\
\hline B & 0,205 & 19 & 0,35 & 0,126 & 19 & 0,200 \\
\hline
\end{tabular}

Sumber : hasil olahh data SPSS

Berdasarkan hasil output uji normalitas, data pretest kelas eksperimen dan kelas kontrol masing- 
masing berada pada kategori berdistribusi normal karena nilai signifikansi $>0,05$ yaitu $(0,281>0,05)$ untuk kelas eksperimen dan $(0,205>0,05)$ untuk kelas control. Begitupun untuk data posttest eksperimen dan kelas kontrol masing-masing berada pada kategori berdistribusi normal karena nilai signifikansi $>0,05$ yaitu $(0,211>0,05)$ untuk kelas eksperimen dan $(0,126$ $>0,0$ 5) untuk kelas Kontrol.

b. Uji Homogenitas

Tabel 5 hasil uji homogenitas terhadap dua kelas

\begin{tabular}{|c|c|r|r|l|}
\hline \multicolumn{5}{|c|}{ Test of Homogeneity of Variance } \\
Kedua Kelas \\
\hline Data & $\begin{array}{c}\text { Levene } \\
\text { Statistic }\end{array}$ & df1 & df2 & Sig. \\
\hline Pre-test & 0,660 & 1 & 6 & 3 \\
\hline Post-test & 2,3980 & 1 & 6 & 0,422 \\
\hline
\end{tabular}

Sumber: hasil olah data SPSS

Pada tabel 5 hasils analisis pre-test dan data post-test menunjukkan bahwa signifikansinya $>\alpha$ artinya kedua data tersebut variansi yang sama (homogen).

c. Uji Hipotesis

Tabel 6 hasil uji hipotesis terhadap dua kelas

Independent Samples Test

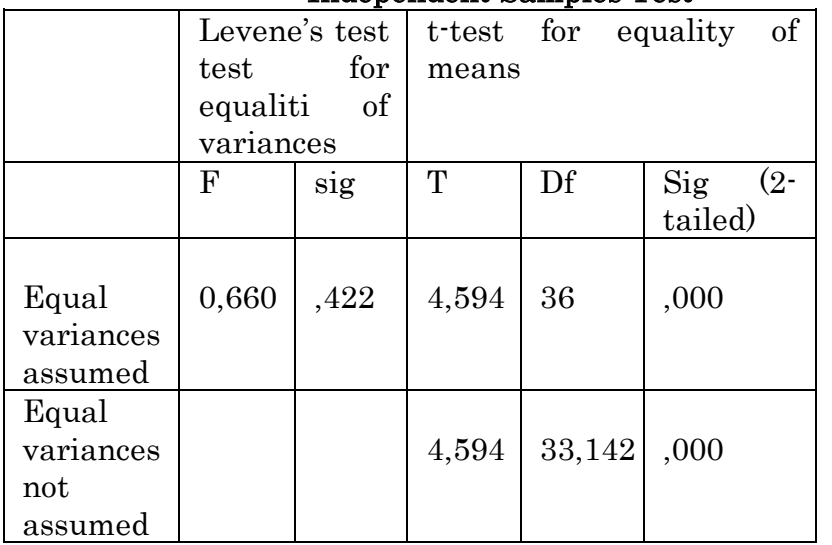

Sumber : olahh data SPSS

Berdasarkan tabel 6 Pengujian hipotesis dilakukan dengan menggunakan uji t. Dimana statistik uji $\mathrm{t}$ diperoleh nilai $t_{\text {hitung }}$ sebesar 4,594. Sedangkan untuk nilai $t_{\text {tabel }}$ sebesar 1,660 yang berarti $t_{\text {hitung }}>$ $t_{\text {tabel }}$ yaitu $4,594>1,660$. ini menunjukkan bahwa $H_{0}$ ditolahk dan $H_{1}$ diterima bila sig $<\alpha$ yaitu $0,000<0,05$. demikian dapat disimpulkan bahwa Hasil Belajar Matematika Siswa melalui metode Problem Solving kelas eksperimen berbeda deanan Metode Konvensional kelas kontrol pada siswa kelas VIII SMP Kristen Kondosapata.
3. Analisis Aktivitas Peserta Didik

\begin{tabular}{|c|c|}
\hline Kelas & $\begin{array}{c}\text { Rata-rata persentase } \\
\text { keseluruhan aktivitas peserta didik }\end{array}$ \\
\hline Eksperimen & $85,75 \%$ \\
\hline Kontrol & $78,59 \%$ \\
\hline
\end{tabular}

Pada kelas eksperimen rata-rata presentase hasil analisis peserta didi pada 3 pertemuan pertemuan yaitu $85,75 \%$, sedangkan kelas kontrol yang juga sebanyak 3 kali pertemuan yaitu $78,59 \%$.

\section{SIMPULAN}

Berdasarkan hasil belajar matematika peserta didik kelas eksperimen diperoleh nilai rata-rata sebesar 81,66. Sedangkan pada kelas kontrol sebesar 78,59. Sehingga disimpulkan bahwa rata-rata hasil belajar pada kelas eksperimen dengan menerapkan metode Problem Solving lebih tinggi dibanding dengan menerapkan metode konvensional pada kelas kontrol.. Ditinjau dari hasil uji $T$ diperoleh nilai $t_{\text {hitung }}$ sebesar 4,594 dan nilai $t_{\text {tabel }}$ sebesar 1,660 yang berarti $t_{\text {hitung }}>t_{\text {tabel }}$ yaitu 4,594> 1,660 artinya $H_{0}$ ditolahk dan $H_{1}$ diterima. Apabila dilihat dari taraf signifikansi $H_{1}$ diterima bila si $\mathrm{g}<\alpha$ yaitu $0,000<0,05$. maka kesimpulan dalam penelitian ini adalah terdapat pengaruh yang signifikan metode pembelajaran problem solving terhadap hasil belajar matematika kelas VIII SMP Kristen Kondosapata

\section{DAFTAR PUSTAKA}

Febryanti, F. (2017). Peningkatan Hasil Belajar Matematika Melalui Metode Pembelajaran Contextual Teaching And Learning. Pepastudzu: Media Pendidikan dan Sosial Kemasyarakatan, 12(1), 14-22.

Ika, Nurmaya. (2017). Pengaruh Penggunaan Mind Map dan Problem Solving dalam Meningkatkan Pemahaman Konsep Matematika Tahun Pelajaran 2016/2017.

Fatimah, F. (2017). Pengaruh pembelajaran berbasis masalah matematis mahasiswa universitas $\mathrm{Al}$ Asyariah Mandar. prosiding, 3(1).

Nadhiroh, Ainin. 2017. Skripsi Pengaruh Penggunaan Metode Pemecahan Masalah Model Polya dengan Strategi Berdendang dan Motivasi Terhadap Hasil Belajar Siswa Kelas VII SMP Islam Durenan.

Eveline, Dra Sireger dan Kartini Nara, M.Si. (2015). Teori Belajar dan Pembelajaran (Bogor: Penerbit Ghalia Indonesia.

Rofikho, Siti. (2017). "Pengaruh Pembelajaran Matematika dengan Problerm Solving terhadap Hasil Belajar". 